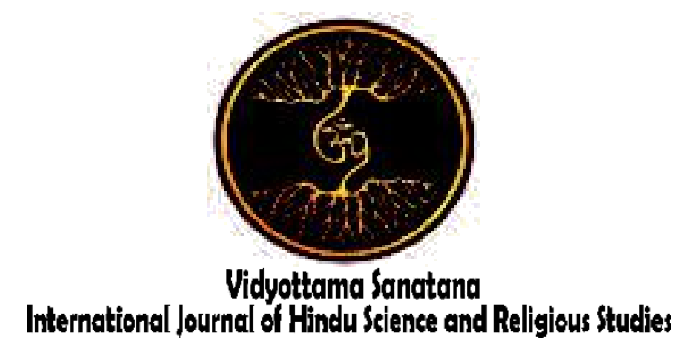

Vol. 2 No. 2 October 2018

\title{
State Defense Diplomacy In Chanakya Viewpoint (Study of Arthashastra Text as a Basis Strategy of Defense Diplomacy)
}

\author{
By: \\ Channarong Chati $^{1}$, Ni Nyoman Ayu Nikki Avalokitesvari ${ }^{2}$, Ni Kadek Surpi ${ }^{3}$ \\ ${ }^{1}$ Khon Kaen University Thailand \\ ${ }^{2}$ Indonesia Defense University \\ ${ }^{3}$ Institut Hindu Dharma Negeri Denpasar \\ E-mail: surpi@ihdn.ac.id
}

Received: August 5, 2018

Accepted: September 23, 2018

Published: October 31, 2018

\begin{abstract}
State defense is a very important aspect in maintaining the existence and sovereignty of a country. Since ancient century Chanakya in a very famous treatise Arthasastra emphasized the importance of diplomacy and efforts to build up the strength of a country. This paper aims to examine the Arthasastra text as the basis of the Defense Diplomacy strategy. Indonesia adopted a Sanskrit slogan in the military world which indicated the close relationship of Indonesian defense and the treasury of Asian civilization with the influence of Indian text. Chanakya asserted, the state must build defense, ready to fight but can maintain peace. A country is deemed to be authoritative so that other countries either with a hostile tendency or as partners, will have high respect. Nevertheless, Arthasastra insists the supreme goal of a country is to build prosperity with defense and security as a prerequisite to build prosperity for a country.
\end{abstract}

Keywords: Defense, Arthasastra, Chanakya

\section{Introduction}

State Defense Diplomacy is very important in maintaining the sovereignty of the state. The national defense has been a necessity for a state since ancient times, evidenced by a number of texts devised for that purpose. In Asia, Arthasastra written by Chanakya is one of the most powerful text.

Arthashastra was composed by Chanakya based on a number of ancient Hindu political books, political traditions, and life experiences. Chanakya's Arthasashtra consists of 32 sections, 15 adikarana with 150 chapters and 600 sloka. Thus Arthashastra can also be said as a compendium of how to manage a State in 
full and detail. For this monumental work, Chanakya is regarded as a legendary Hindu political figure, whose genius is often matched with western philosophers and statesmen like Plato, Aristotle, and Machiavelli.

Extraction and deeper interpretations helps Arthashastra to discover its relevance, amidst the dynamic in today's times. If Chanakya's thoughts in Arthashastra interpreted literally may seem outdated and no longer relevant. However, if the interpretation is adjusted to the current situation development it may still be relevant. For example, about The Mandala Theory. Mostly western thinkers merely emphasizes it into "every neighbor is an enemy, and the enemy of your enemy is your friend" ${ }^{1}$. Yet, if we behold only from this understanding alone, then the theory of Chanakya mandala will look so realist and difficult to be applied in the present day. Because it is contradictory to the regime of regionalism which indirectly requires neighboring countries to cooperate each other to reach common purposes. Even today, it would be difficult to a country and even even very rarely that they can show hostile conditions directly as well as openly with their neighbors.

Meanwhile R.P Kangle insisted that Chanakya did not really hit the whole country that neighbors were enemies. This is discussed in the seventh book, chapter 18 of the 29th sutra, that "The princes of the neighboring country, samantas, are usually considered hostile. But it is possible that some of them may have feelings of kindness towards vijigisu (middle state), while others may even submit to him. The neighboring countries are divided into three categories; Aribhavin (from hostile disposition), mitrabhavin (from friendly disposition) and bhrytyabhavin (from the disposition of brotherhood)"2. Examining from the explanation above, actually a country needs

\footnotetext{
${ }^{1}$ L.N. Rangarajan, The Arthashastra, Penguin Books, New Delhi, 1992, Preface, p. viii.

${ }^{2}$ R.P. Kangle, The Kautilya Arthasastra, Part 3, no. 14, p. 250
}

to map out the way which can be used to deal with its neighbors. How does the state map the countries as competitors to be raised in cooperation, whichever needs to be give a special attention, which ones have the potential to be a latent threats, and whichever is the potential for mutual benefit.

In Arthashastra, Kautilya offers an extensive and truly interesting discussion of war and diplomacy. Chanakya in his Arthashastranya discusses the dynamics of monetary and fiscal policy and its relation to people's welfare, international relations, and war strategies. According to Chanakya, if a State wants to have power in relations with other countries, wants to win the war, then the State must have a strong economy. Chanakya also gives emphasis on the figure of energetic and dynamic leader who takes a country to improve the country's charisma and influence. Because if the leader is energetic, the people and the economy will also wriggle, while if the leader is lazy and slow, the same thing will happen to the state.

Although it has been acknowledged as one of the books that provides an understanding of diplomacy and defense of the State, but until now not much schoolar in Indonesia, both the political scientists and the international relationship studyers who discuss and get to know both Arthashastra concepts. In fact, almost there's no textbook of International Relations in Indonesia talks about Kautilya Arthashastra as the focus of their discussion. Most of them are focused only on international relations studies with western perspectives. Similarly, the concepts of diplomacy and national defense in Indonesia still very western oriented. Yet it cannot be denied that the dominance of western theory in the science of international relations and defense diplomacy contains theoretical bias because of cultural values that are different from the situation in Indonesia.

Yet, if we observed the approach used in the Indonesian Defense System was not always oriented to western theories. The defense system applied by the TNI in Indonesia has its own uniqueness. The use of 
Javanese philosophy in management and the practice of leadership in the early formation of the military in Indonesia given its own color to the military in Indonesia. During the time of President Soeharto, for example, the Old Javanese philosophy such as "Hasta Brata" which combined with Sapta Marga became the benchmark of leadership. Similarly, the use of Sanskrit terminology (adopted by the writing of Ancient Javanese) on the Military Defense Doctrine and the doctrines prevailing in each of the TNI dimensions.

The Indonesian Military Defense Doctrine is Tri Dharma Eka Karma, which is translated into three dimensions namely, Military Defense Doctrine of the Army "Kartika Eka Paksi", Military Defense Doctrine of the Navy "Jalesveva Jayamahe" and Military Defense Doctrine of the Air Force "Swa Bhuana Paksa" Doctrine. This makes the authors want to examine further the possibility of fusion or assimilation of values from books and scriptures derived from India, in this case Arthashastra to be a paradigm in the strategy of defense diplomacy. The author wants to see how the values and concepts contained in the Arthashastra texts can form the basis of the concept of defense diplomacy, especially in the context of Indonesia's defense diplomacy.

\section{Methods}

This study is a text study that examines the values and ideas of statecraft, threat mapping, and diplomacy contained in the Arthashastra text. Where the three concepts mentioned above will be a common thread that provides an intratext relationship on the concept of defense diplomacy in Arthashastra. So then obtained the output of the concept of defense diplomacy by Arthashastra which can be used as a reference paradigm and the concept of nonwestern defense diplomacy in carrying out defense diplomacy strategy. The main data source of this research is Arthashastra Text and supporting data obtained from the study, comments and expert interpretation of the concepts contained in the Arthashastra in the form of books, journals, dissertations or other scientific papers. Similarly other supporting data obtained from interviews with experts, especially experts in the field of Arthashastra and National Defense.

This research will be focused on how the values of diplomacy in Arthashastra can be used as a basis in carrying out defense diplomacy that is not only based on western theories.

\section{Theory / Calculation}

This study uses the Paul Ricoeur Interpretation Theory. In his theory, Paul Ricoeur seeks to bridge the problem of discourse that has been going on for a very long time and has become a problem by Plato and Aristotle. Ricoeur started his discussion with the theme of language as a discourse. Ricoeur says (2012: 18) this is the first context in which the concept of discourse is known, that mistakes and truths are the affection of discourse and discourse to establish two basic signs, one noun and one interrelated verb in the synthetic form (meaningful) behind the well said word. Furthermore, Ricoeur stated (2012: 19) in this modern linguistics, the problem of discourse becomes an original thing because today's discourse can be contradicted by a contradictory term which unknown or not justified by ancient philosophers.

\section{Results and Discussion}

Chanakya or Kautilya have realist thought, diplomacy is another weapon used in the ongoing or planned battle of the prolonged warfare that was always occurring or being planned for. This is because Chanakya assumes that the country lives in a world of international relations where there are only two choices, between conquering or conquered. So, he no longer says "get ready to fight but still hope for peace". Chanakya says otherwise, "prepare for war and plan to conquer." When Carl Von Clausewitz declared that war is an extension of domestic politics, Chanakya argues that diplomacy is a subtle act of war, a series of actions undertaken to weaken the enemy and benefit 
the country itself, everything is done with an eye toward conquest.

$$
\text { "In this way, the }
$$
conqueror should establish in the rear and in front, a circle (of kings) in his own interest. ... And in the entire circle, he should ever station envoys and secret agents, becoming a friend of the rivals, maintaining secrecy when striking again and again. The affairs of one, who cannot maintain secrecy, ... undoubtedly perish, like a broken boat in the ocean."

For Chanakya, foreign policy is simply an extension of a state of war. Since the purpose of foreign policy is not to stop the war, but rather an attempt to fend off the defeat and ensure success in the next war. For Chanakya, this foreign policy principle that countries act in their political, economic, and military interests - is the eternal truth of their political science, or Arthashastra. He does not believe that nations never act in an altruistic way - indeed, Chanakya advocates a humanitarian act that also coincides with personal interests - but he believes that one should assume, if it is entrusted with political or military power that his neighbors will ultimately act to achieve their own interests.

Associated with diplomacy and foreign policy, Chanakya sparked Shadgunya Theory or better known as the Six-fold Foreign Policy or six methods of foreign policy. Six foreign policy is the determination Kautilya (policy) either to retreat, stable / silent or go forward. Sixth political policies are making peace (sandhi), fighting (vigraha), idle / neutral (asana), prepare for war / standby (yana), seeking support / alliances (samsraya), and the dual policy of making peace with one state while also waging war with other countries ${ }^{4}$. The ongoing conditions will determine what policies should be used.

\footnotetext{
${ }^{3}$ Kautilya Arthashastra 7.13. 42-44: 366

${ }^{4}$ Ibid
}

For peace, we must first engage in an agreement, such as an agreement, on certain conditions. But in the existing agreement that requires certain conditions, or may not have any obligation. The unconditional agreement is generally used to obtain information about the enemy, so the king can attack after learning the weak points of his 'opponents'. Covenants with certain obligations allow a "prudent king to make the king of a neighboring country fight against another neighboring state to prevent them from uniting and attacking him". The only way the king actually makes peace is when he finds himself in a relative setback when compared to his enemy.

The study of elites and political leaders is one of the most important pillars of political science. The statecraft itself is a framework for learning about it, first developed by Jim Bupitt, an academic from England in 1986. The statecraft approach is concerned with how the political elite confronts, responds and manages emerging challenges. $^{5}$ Dr. John Lenczowski, the Founder and President of the Institute of World Politics (IWP) stated that statecraft is an art in the use of national power instruments to achieve the goal of defending vital national interests, international relations, and ultimately the cause of peace in the world. Various instruments included include military strategy, art of diplomacy, various types of public diplomacy involving relations with people and also with foreign influences as opposed to traditional diplomacy involving relations with rulers. Other statecraft art including intelligence and counter-intelligence ${ }^{6}$.

For Machiavelli statecraft is a skill that must be owned by a statesman. This statecraft is also related to the way it uses its

\footnotetext{
${ }^{5}$ James, Toby S. 2016. Neo-Statecraft Theory, Historical Institutionalism and Institutional Change. University of East Anglia. Diakses dari https://ueaeprints.uea.ac.uk/54729/1/James_GOV_f or_web.pdf

${ }^{6}$ Lenczowski, John. 2017. What is Statecraft. The Institution of World Politics. Diakses dari https://www.youtube.com/watch?v=GdN4Sh1RjkU
} 
power, to achieve a larger goal (state goal). Machiavelli states that a great and great country is a country that is respected by many other countries. Respectfully refers to the sense of being respected and feared but at the same time can be consulted for protection. To achieve this the state must have a strong army formed from its own people through compulsory military training. A strong and glorious country is also required to have a competent and clever ruler in order to preserve his power from conspiracies or coup attempts both domestically and in foreign aid. The other important thing is that this ruler must have people who are obedient to the ruler and ready to defend the state and the rulers of various types of threats that endanger the existence of the rulers and their state. ${ }^{7}$

Meanwhile, statecraft Indonesia in the era of the kingdom was first discussed in the work of "Negara dan Usaha Bina Negara di Masa Lampau" by Soemarsaid Moertono. The relationship between the people and the king / ruler here is referred to as kawulo lan gusti. A king without any people then the power possessed becomes useless. The king should have the wisdom to be respected by the people. The wise nature includes fair behavior in problem solving, and is responsible for the people being led. Another characteristic that the leader must possess is also embedded in the concept of astabrata. Noble / Priyayi also have an important role in the state system in the kingdom of Mataram era used as material pememasan by Moertono. The priyayi (aristocrat) are the king's accomplices. They are in charge of all conditions within a kingdom. The territory of the kingdom during this period of governmental concept is divided into two, Negaragung and mancanegara. This overseas area is led by a regent, who is a servant of the King, and must submit to the king's command ${ }^{8}$.

\footnotetext{
${ }^{7}$ Butterfield, Herbert. The Statecraft of Machiavelli. New York: Collier Books, 1967

${ }^{8}$ Moertono, Soemarsaid. 1985. Negara dan Usaha Bina-negara di Jawa Masa Lampau: Studi tentang
}

Regarding the effort to obtain or extend their teritory, King had three ways. First, is through violence or war. The second is by forcing an influential person in a certain area (to be occupied) to stay within the palace in a certain time period while his territory is left to be administered by the palace officials. While the last way is to establish fellowship through marriage. ${ }^{9}$

On the other hand, in Arthashastra, governance is incorporated into a theory called the Saptanga Theory. Sapta in Sanskrit means seven and anga means body parts. Thus saptanga refers to the seven-fold sense of the body. The state in Artashastra is analogous to a growing organism and prakritis is part of its body. ${ }^{10}$ These seven parts are: Swamin (Ruler); Amatya (concilors); Janapada (Territory / resources); Durg (Well-fortified Sovereign entity); Kosa (Treasury); Danda / Bala (Military / Army and order keeping); and Mitra (Friend / Ally). ${ }^{11}$

As part of the body, the seventh element cannot be separated and are needed for the growth of the country as a whole. Each part plays an important role. In general the order of importance is declining in the sense Swamin is more important than amatya, then janapada, durg, kosa, bala, and the last is mitra. But in reality, this order is not very important, especially if the country is faced against a specific threat, this order can be changed dynamically. Because for Chanakya caution is important from the rules. He did not take anything for granted. So he writes "'[Lastly] a calamity which threatens to destroy all of the other things shall be regarded as [the most] serious, irrespective of what the position occupies in the list of priorities." 12

Statecraft in Arthashastra intended to achieve what is referred to as yogakshema

\footnotetext{
Masa Mataram II, abad XVI sampai XIX. Yayasan Obor Indonesia.

${ }^{9}$ Ibid.

${ }^{10}$ Sukra, Sukraniti, Mumbai: Khemraj Shrikrisnadass,

2012, chapter 1 , sutra 62

${ }^{11}$ Kautilya Arthashastra 6:1

${ }^{12}$ Kautilya Arthashastra 8:1.63
} 
which means enjoying the peace that obtained from welfare / prosperity, that prosperity and security simultaneously. According to Kautilya, an insecure country can be easily conquered, and thus will be under the rule of a foreign ruler and face exploitation. Kautilya believes that national security is very important for prosperity and having good troops is an important factor in the provision of national security. He also understands that prosperity is essential to national security because poor countries can not have the resources to maintain their security. Thus, he believes that national prosperity and security are interdependent. ${ }^{13}$

According to Chanakya for the sake of the nation's prosperity, a king must be vigilant in forecasting the possibility of a disaster, trying to prevent it before they emerge, overcoming it, removing all obstacles to economic activity and preventing loss of income. Discussing about the power of a state, or "national power", Kautilya Arthashastra identifies three shaktis: utsahashakti, prabhavashakti and mantrashakti. Utsahashakti means the power to give impetus, energy, and direction to the state and its elements, and especially to the ruler or king. In modern times, it can be likened to the leadership of a country. Prabhavashakti means the power to produce 'effects' that benefit the state, and relates to the economy and military power of a country. Finally, mantrashakti means the power to influence, attract, and encourage cooping. In contemporary terms, it is related to good advice and diplomacy.

In Arthashastra, Six foreign policy policies are discussed in the seventh book ${ }^{14}$. In this book Kautilya offers the theory that "an immediate neighboring state is an enemy and a neighbour's neighbor, separated from oneself by the intervening enemy, is a

\footnotetext{
${ }^{13}$ Malay Mishra (2016): Kautilya's Arthashastra:

Restoring its Rightful Place in the Field of

International Relations, Journal of Defence Studies,

Vol. 10, No. 2 April-June 2016, pp. 77-109

${ }^{14}$ Kautilya, 2003, Arthasastra, Surabaya: Paramita.p. 389-476
}

friend" ${ }^{15}$. Why would Kautilya regard the immediate territory of the State as an enemy, while far apart is a friend. To explain it Kautilya made a worldview called the Mandala theory, in which neighboring neighbors were regarded as natural enemies, but any country whose territory was blocked by an enemy country / competitors was considered an ally, or, the enemy of my enemy was a friend to me.

Kautilya laying the basic principles in a number of different ways, but the simplest is, "A country whose territory is directly adjacent is a natural enemy." Then he stated the theory of foreign policy Mandala with more detail: "With regard to the presence of the middle king (i.e himself), then the third and fifth elements / kings are the friendly elements. The fourth, and the sixth, are the unfriendly elements. "Thus the conquering state can influence the line between the allies and the enemy, just as the conquering king influences the distinction between the allies and the enemy.

Kautilya describes the Mandala or Circle of States as a wheel with the conqueror as its central. Allies are pulled towards its position along the radius of the wheel even though they are separated by the enemy's territory ${ }^{16}$. When considered appropriate, the conquering king implements six methods of foreign policy, commonly known as the six-fold policy, against the various components of the Mandala of States. The method works interrelated and bind to one another to the conqueror so that he (the conqueror king) can do whatever it wants as long as it is necessary based on Kautilya's foreign policy is the determination of the (policy) retreat, stable / silent and forward.

Roger Boesche (2003) through his writings entitled Kautilya's Arthashastra on War and Diplomacy in Ancient India lays out a discussion of war and diplomacy

\footnotetext{
${ }^{15}$ L.N. Rangarajan, The Arthashastra: Edited, Rearranged, Translated and Introduced, (New Delhi, India: Penguin Books India Ltd, 1992), p. 542. ${ }^{16}$ Ibid, p. 561
} 
according to Chanakya. This paper published in The Journal of Military History, Vol. 67 No. 1, January 2003, page 9-37. It presents Chanakya's analysis of which kingdom is the enemy and natural ally of a country, the doctrine of a silent war, the use of secret agents that can kill enemy's leaders and disperse disputes among the enemy, about women as weapons of war, strengthening troops to demoralize enemy armies, dissemination of disinformation, and the humane treatment of soldiers and subjects who have been conquered ${ }^{17}$. This knowledge will be very useful for defense reference in Indonesia while increasing awareness. In this era silent war is preferred to destroy a civilization, so Indonesia should be wary and find ways to deal with it. Arthasastra became a strong reference to face the long-standing secret war in the world, including in Indonesia.

Lieutenant Colonel Malay Mishra (2017) through his article entitled "Unique Approach to Comprehensive National Power through the Lens of Kautilya's Arthashastra" provides an explanation of the comprehensive National Strength of a country. The paper, published in the Journal of the United Service Institution of India Vol. CXLVII, No. 607. January-March 2017 also provides a comparison of views on comprehensive national power formulations from both western, Chinese, and Arthashastra constructions. Mishra also describes the Saptanga Theory State, a view of Chanakya on how the state should be (Ideal State) which is then run with the Six Foreign Policies (Shadgunya) ${ }^{18}$. Indonesia needs to take seriously its Shadgunya to build its national power formation.

Major Abhishek Kumar (2016), through his writings entitled "The

\footnotetext{
${ }^{17}$ Boesche, Roger. 2003. Kautilya's Arthasastra on War and Diplomacy in Ancient India. The Journal of Military History, Vol. 67 No.1 January 2003. Hal. 9-37 ${ }^{18}$ Mishra, Malay. 2017. Unique Approach to Comprehensive National Power through the Lens of Kautilya's Arthashastra. Journal of the United Service Institution of India, Vol. CXLVII No. 607, JanuaryMarch 2017
}

Arthashastra: Assessing the Contemporary Relevance of Ancient Indian Treatise on Statescaft" seeks to elaborate on the work of statecraft and its relevance to its present state. The Thesis of the College's Faculty of U.S Army Command and General Staff found that Chanakya's priorities on the elements of the country's national strength and its focus on strengthening state power, found common ground in contemporary Chinese policy choices. This paper also describes the analysis of China's contemporary geopolitical environment in Kautilya's doctrine. This paper also explains that Kautilya's Concepts of Prakrti (elements of the state's constituents), relative power models, and Vyasana concepts (calamities affecting the constituent elements of the state) offer a viable path to optimizing a nation's national power ${ }^{19}$.

Defense concepts in Arthasastra are very likely to be applied in Indonesia to build the power of the state with the sovereignty of the state and respected in the world. Similarly, in Arthasastra, all forms of state defense actually boils down to the welfare of the people as the highest goal. Nevertheless, various aspects of defense are still open for further research.

\section{Conclusions}

Defense diplomacy is very important for a country. Chanakya, an ancient Indian state architect who wrote the famous treatise Arthasastra has formulated a number of defense concepts and strategies. Indonesia, though not fully adopt Chanakya defense art, but got a great influence of India through a number of texts such as the Ramayana and Mahabharata, particularly in the areas of leadership and military power. Chanakya in his famous treatise Arthasastra not only talks about defense and war, but his ultimate goal is prosperity. A prosperous country will be able to build a very strong defense aspect in

\footnotetext{
${ }^{19}$ Kumar, Abhishek. 2015. The Arthashastra: Assessing the Contemporary Relevance of an Ancient Indian Treatise on Statescaft. Tesis. Faculty of U.S Army Command and General Staff College
} 
which the people are a very important element of strength.

\section{References}

Boesche, Roger. 2003. Kautilya's Arthasastra on War and Diplomacy in Ancient India. The Journal of Military History, Vol. 67 No.1 January 2003. Hal. 9-37

Butterfield, Herbert. 1967 The Statecraft of Machiavelli. New York: Collier Books.

James, Toby S. 2016. Neo-Statecraft Theory, Historical Institutionalism and Institutional Change. University of East Anglia. Diakses dari https://ueaeprints.uea.ac.uk/54729/1/J ames_GOV_for_web.pdf

Kangle, R.P. 1986. The Kautilya Arthasastra, Part 3, no. 14, Motilal Banarsidass Publ., 1986. p. 250

Kautilya, 2003, Arthasastra, Surabaya: Paramita.p. 389-476

Kumar, Abhishek. 2015. The Arthashastra: Assessing the Contemporary Relevance of an Ancient Indian Treatise on Statescaft. Tesis. Faculty of U.S Army Command and General Staff College

L.N. Rangarajan. 1992. The Arthashastra: Edited, Rearranged, Translated and Introduced, (New Delhi, India: Penguin Books India Ltd, 1992), p. 542.R.P. Kangle, The Kautilya Arthasastra, Part 3, no. 14, p. 250
Lenczowski, John. 2017. What is Statecraft. The Institution of World Politics. Diakses dari https://www.youtube.com/watch?v= GdN4Sh1RjkU

Mishra, Malay. 2016. Kautilya's Arthashastra: Restoring its Rightful Place in the Field of International Relations, Journal of Defence Studies, Vol. 10, No. 2 April-June 2016, pp. 77-109

Mishra, Malay. 2017. Unique Approach to Comprehensive National Power through the Lens of Kautilya's Arthashastra. Journal of the United Service Institution of India, Vol. CXLVII No. 607, January-March 2017

Moertono, Soemarsaid. 1985. Negara dan Usaha Bina-negara di Jawa Masa Lampau: Studi tentang Masa Mataram II, abad XVI sampai XIX. Yayasan Obor Indonesia.

Puspawati, L. P., Ariana, I. K. E., \& Suastika, I. M. (2018). An Ecological Aspect Of The Text Kuttara Kṇḍa Dewa Purāna Bangsul Concerning Mount Batukaru. Vidyottama Sanatana: International Journal of Hindu Science and Religious Studies, 2(1), 163-174.

Ricoeur, Paul, 2012, Teori Interpretasi: Memahami Teks, Penafsiran dan Metodologinya, IRCiSoD, Yogyakarta

Sukra. 2012. Sukraniti, Mumbai: Khemraj Shrikrisnadass, 2012, chapter 1, sutra 62 